\title{
LENGTH-WEIGHT RELATIONSHIP, CONDITION FACTOR AND FECUNDITY OF AFRICAN SNAKEHEAD Parachanna obscura FROM THE ANAMBRA RIVER, SOUTH EAST NIGE- RIA
}

\author{
Friday Elijah Osho*, Ridwan Abiola Usman
}

Department of Aquaculture and Fisheries Management, University of Ibadan, Oyo state, Nigeria

*Corresponding Author, Email: oshofriday@yahoo.com

\section{ARTICLE INFO}

Received: 29 July 2017

Accepted: 10 March 2019

\begin{abstract}
The length-weight relationship, condition factor, fecundity, gonadosomatic and hepatosomatic indices of Parachanna obscura from the Anambra River were determined between December 2015 and June 2016. Eighty-three live samples of $P$. obscura were obtained from fishermen. Descriptive statistics, correlation and regression analysis were used to analyze the obtained data. The length-weight relationship had $R$ values of $0.933,0.843$ and 0.896 for male, female and combined sexes, respectively. The $b$ value of 3.133 for male and 2.674 for female were not significantly different $(P>0.05)$. Mean condition factors of $0.89 \pm 0.33$ and $0.80 \pm 0.21$ were obtained for female and male, respectively. The largest number of eggs $(10,965)$ was found in a female with the body weight of $154 \mathrm{~g}$, gonad weight of $9.1 \mathrm{~g}$ and egg size of $1.3 \mathrm{~mm}$, while the least fecund female with 1820 eggs weighed (94 g) and had a gonad weight $2.1 \mathrm{~g}$ with egg size of $1.0 \mathrm{~mm}$. The hepatosomatic indices ranged between $0.55 \pm 0.20$ and $0.64 \pm 0.29$ in both male and female, respectively, while female gonadosomatic index average was 2.05 \pm 1.44 . There was a positive correlation between fecundity and gonad weight.
\end{abstract}

Osho, F. E., Usman, R. A. (2019): Length-weight relationship, condition factor and fecundity of African snakehead Parachanna obscura from the Anambra River, South East Nigeria. Croatian Journal of Fisheries, 77, 99105. DOI: 10.2478/cjf-2019-0011.

\section{INTRODUCTION}

Parachanna obscura is an important food and aquarium fish that is widely loved in Africa for its gastronomic qualities (Whenu and Fagade, 2012). However, this fish has been documented by IUCN (2016) as an endangered species. A better understanding of the natural populations of this fish is needed for proper conservation and exploitation. For ages, studies on the length-weight relationship, condition factor and fecundity are imperative for proper management decisions and conservation of aquatic resources. They are important prerequisites to a more detailed study on their breeding and production. Condition factor is essential in understanding the life cycle of fish species and contributes to adequate management of these species (Imam et al., 2010). The length-weight relationship is a useful tool in fish growth pattern (Pepple and Ofor, 2011) and for the estimation of mortality, recruitment and other parameters of population. Such information is also important for fish stock assessment 
and understanding the population dynamics, which could serve as a valuable and useful tool in the management of the species. The Anambra River is a major source of $P$. obscura and other wild caught fishes all year round in South East Nigeria (Eyo and Mgbenka, 1992). Jamu and Ayinla (2003) reported that the fish yields of most Nigeria's inland waters were generally on the decline. However, Anyanwu et al. (2009) reported the fisheries economy of this river was profitable and suggested that scientific measures be taken to sustain this. An understanding of the fisheries of this river will contribute to the goal of its sustainable exploitation and utilization of its resources. Therefore, this study investigated the length-weight relationship, condition factor and fecundity of $P$. obscura in Anambra State.

\section{MATERIALS AND METHODS}

\section{Experimental site}

This study was carried out in the River Anambra, South East Nigeria. The River basin lies between latitudes $6^{\circ} 10^{\prime}$ and $7^{\circ} 20^{\prime} \mathrm{N}$ and longitudes $6^{\circ} 35^{\prime}$ and $7^{\circ} 40^{\prime} \mathrm{E}$ in the Southeast of Nigeria.

\section{Collection of specimens}

Eighty three $P$. obscura samples were obtained from the fishermen's catch at Otuocha landing site of the Anambra River, Nigeria between December 2015 and June 2016. The fish were transported in a 50-litre keg to the Fisheries Laboratory of Department of Fisheries and Aquaculture Management, Nnamdi Azikiwe University, Awka, Nigeria. Morphometric analysis

Body weight was measured to the nearest $0.1 \mathrm{~g}$, total length and standard length were measured to the nearest $0.1 \mathrm{~cm}$. The length-weight relationships were determined by linear regression techniques for both sexes, as well as length and weight of the fish, using the following equation $\mathrm{W}=\mathrm{aL}^{\mathrm{b}}$ (Ricker, 1971). Where Taking the logarithm: $\log W=\log a+b \log S L$

$\mathrm{W}=$ Weight of the fish $(\mathrm{g})$

$\mathrm{SL}=$ Standard length of the fish $(\mathrm{cm})$

$\mathrm{a}=$ the regression constant which is also the intercept $b=$ the regression of coefficient

\section{Condition factor ( $K$ )}

The condition factor which measures the relative wellbeing of the fish was calculated for both sexes using $\mathrm{K}=100 \mathrm{~W} / \mathrm{L}^{3}$ by Tesch (1978):

$$
\mathrm{K}=\text { Condition factor; } \mathrm{W}=\text { Weight }(\mathrm{g}) ; \mathrm{L}=\text { Length }(\mathrm{cm})
$$

\section{Gonadosomatic index (GSI)}

The fish were dissected and the ovaries were exposed and were taken out carefully. Weight of gonads was taken with weighing balance and finally the GSI value of the specimen was calculated. This was expressed as percentage of the gonad weight (GW) in terms of body weight (BW) of the fish (Afonso-Dias et al., 2005).

$$
\mathrm{GSI}=\text { Gonad weight }(\mathrm{g}) / \text { Body weight }(\mathrm{g}) \times 100
$$

\section{Hepatosomatic index (HSI)}

The fish liver were carefully removed and weighed on electronic scale to the nearest $0.01 \mathrm{~g}$. The hepatosomatic index (HSI) was calculated as a percentage of the liver to the body weight using $\mathrm{HSI}=$ Liver weight $(\mathrm{g}) /$ Body weight (g) $\times 100$

\section{Fecundity determination}

Samples of a known weight were taken from the anterior, middle and posterior regions of each ovary and kept in a bottle containing $10 \%$ formalin solution for preservation. The subsamples were preserved in $10 \%$ formalin solution. After 24 hrs eggs became larger and separated from each other. The eggs in the subsamples were counted under a magnifying glass and weighed. Thereafter, the mean values of eggs were computed. Then the fecundity of the collected specimens was calculated according to Yeldan and Avsar (2000).

Using:

$$
\begin{aligned}
& \mathrm{F}=\text { Ovary weight } \times \text { number of eggs in the subsamples/ } \\
& \text { subsample weight }
\end{aligned}
$$

Diameter of randomly selected eggs was measured with digital micrometer to the nearest $0.01 \mathrm{~mm}$.

\section{Data analysis}

The condition of the fish was expressed by Fulton's condition factor $(\mathrm{K})$, calculated using the formula: $\mathrm{K}=$ $100 \mathrm{~W} / \mathrm{L}^{3}$. Descriptive statistics and regression analysis were used to analyze the morphometric parameters. Relationships between variables (length vs. weight, fecundity vs. body weight/length) were analyzed using correlation analyses.

\section{RESULTS}

\section{Length-weight relationship}

A total of 83 samples of $P$. obscura were examined in this study, of which 36 were females and 47 were males. The samples ranged in total length from 18.70 to 34.50 $\mathrm{cm}$ with the mean of $26.16 \pm 4.41 \mathrm{~cm}$, and from 17.20 to $34.70 \mathrm{~cm}$ with the mean of $25.76 \pm 3.58 \mathrm{~cm}$ for male and female, respectively. The total weight ranged from 47.00 to $320.00 \mathrm{~g}$ with the mean of $156.11 \pm 82.66 \mathrm{~g}$, and from 40.00 to $355.00 \mathrm{~g}$ with the mean of $157.97 \pm 74.18 \mathrm{~g}$ for male and female, respectively, as presented in Table 1. The regression model indicating the relationship between length-weight of male, female and combined sexes of $P$. obcura had $R^{2}$ values of $0.870,0.709$ and 0.803 , respectively, at significant level of $P<0.05$. Coefficients of length (b) of male (with value of 3.133) were positive while those of the female and combined sexes (with values of 2.674 and 2.956 , respectively) were negative. 
Table 1. Mean values of weight (W), total (TL) and standard length (SL) of different sexes of Parachanna obscura collected from the Anambra River $(p<0.05)$

\begin{tabular}{|c|c|c|c|c|c|c|c|}
\hline & \multicolumn{2}{|c|}{ Male } & \multicolumn{2}{|c|}{ Female } & \multirow{2}{*}{ P-value } & \multicolumn{2}{|c|}{ Combined sexes } \\
\hline & Mean \pm SD & Min.-Max. & Mean \pm SD & Min.-Max. & & Mean $\pm S D$ & Min.-Max. \\
\hline W (g) & $156.11 \pm 82.66$ & $47.00-320.00$ & $157.97 \pm 74.18$ & $40.00-355.00$ & 0.915 & $156.92 \pm 78.63$ & $40.00-35.500$ \\
\hline $\mathrm{TL}(\mathrm{cm})$ & $26.16 \pm 4.41$ & $18.70-34.50$ & $25.76 \pm 3.58$ & $17.20-34.70$ & 0.656 & $25.99 \pm 4.05$ & $17.20-34.70$ \\
\hline $\mathrm{SL}(\mathrm{cm})$ & $21.83 \pm 3.77$ & $15.40-29.30$ & $21.40 \pm 3.15$ & $14.20-28.90$ & 0.581 & $21.64 \pm 3.50$ & $14.20-29.30$ \\
\hline
\end{tabular}

\section{Condition factor (K)}

Table 2 indicates the mean values of the condition factors of both sexes of $P$. obscura. The condition factor of both sexes of $P$. obscura ranged between 0.59 and 2.34, while the female and male samples had mean values of $0.89 \pm 0.33$ and $0.80 \pm 0.21$, respectively. The statistical analysis indicated that there was no significant difference $(P>0.05)$ in the condition factors of both sexes of fish samples collected.

Table 2. Condition factor (K) and hepatosomatic index (HSI) of different sexes of Parachanna obscura collected from the Anambra River

\begin{tabular}{lccccc}
\hline \hline Parameter & Sex & N & Mean \pm SD Min-Max & P-value \\
\hline K & Female & 36 & $0.89 \pm 0.33$ & $0.59-2.34$ & 0.116 \\
& Male & 47 & $0.80 \pm 0.21$ & $0.44-1.68$ & \\
HSI & Female & 36 & $0.55 \pm 0.20$ & $0.22-1.06$ & 0.09 \\
& Male & 47 & $0.64 \pm 0.29$ & $0.31-1.56$ & \\
\hline \hline
\end{tabular}

\section{Hepatosomatic index (HSI) and gonadosomatic index} (GSI)

Presented in Table 2 are the mean and range values of HSI and female GSI of P. obscura. The hepatosomatic index ranged between 0.31 and 1.56 with the mean of $0.64 \pm 0.29$, and between 0.22 to 1.06 with the mean of $0.55 \pm 0.20$ for both female and male, respectively. The statistical analysis indicated that there was no significant difference $(P>0.05)$ in the mean $\mathrm{HSI}$ for both sexes. However, the GSI ranged between 0.50 and 5.84 with the mean of $2.05 \pm 1.44$.

\section{Fecundity}

Fifty per cent of the female $P$. obscura studied was found to be fecund (Table 3). The highest number of eggs $(10,965)$ was found in a female with the total length of $26.2 \mathrm{~cm}$, body weight of $154 \mathrm{~g}$, gonad weight of $9.1 \mathrm{~g}$ and egg size recorded was $1.3 \mathrm{~mm}$. Meanwhile, the smallest fecund female had 1820 eggs which measured $22.1 \mathrm{~cm}$ in total length, $94 \mathrm{~g}$ in body weight, with gonad weight of 2.1 $\mathrm{g}$ and egg size of $1.0 \mathrm{~mm}$.
Table 3. Mean Fecundity, egg size, gonad weight, and gonadosomatic index of female Parachanna obscura samples collected from the Anambra River

\begin{tabular}{lcc}
\hline \hline \multicolumn{1}{c}{ Parameter } & Mean \pm SD & Min-Max \\
\hline Fecundity (F) & $5263.00 \pm 3343.73$ & $1820.00-10965.00$ \\
Egg size (ES) (mm) & $1.10 \pm 0.50$ & $0.90-1.30$ \\
$\begin{array}{l}\text { Gonad weight(g) } \\
\begin{array}{l}\text { Gonadosomatic } \\
\text { Index }\end{array}\end{array}$ & $3.30 \pm 2.76$ & $0.80-10.00$ \\
\hline \hline
\end{tabular}

\section{Fecundity, egg size and some growth and reproductive parameters}

The relationships of fecundity with gonad weight and egg size were significant $(P<0.05)$, as shown in Table 4. There were strong correlations between total length and standard length. Fecundity was weakly correlated with total length and standard length. However, there were negative correlations between fecundity and condition factor, egg size and condition factor, total length and condition factor with the values of $-0.113,-0.030$ and -0.270 , respectively. Among all correlated variables, fecundity and gonad weight were the highest. This was closely followed by total length and standard length.

\section{DISCUSSION}

The results of the present study revealed that $P$. obscura exhibited negative and positive allometric growth pattern with regression analysis exponent $b$ values less than and greater than 3 in females and males, respectively. The ' $b$ ' values in length-weight relationships determine the growth pattern of the fish species. Though the $b$ values for both sexes were not significantly different, the result conforms to the observations of Osho et al. (2014) that the males of many tropical species grow faster and have more standard sizes than females, probably due to beneficial anabolism enhancing androgens. This result also corroborated the findings of Obasohan et al. (2012) who reported negative allometric growth pattern in five different fish species including $P$. obscura from Ibiekuma stream, Ekpoma, Edo state, Nigeria. Imam et al. (2010) 
Table 4. Pearson Correlation Matrix for Parachanna obscura from the Anambra River

\begin{tabular}{|c|c|c|c|c|c|c|c|}
\hline & Weight (g) & $\begin{array}{l}\text { Total Length } \\
(\mathrm{cm})\end{array}$ & $\begin{array}{c}\text { Standard } \\
\text { Length }(\mathrm{cm})\end{array}$ & Fecundity ' $F$ ' & $\begin{array}{l}\text { Condition } \\
\text { Factor ' } K \text { ' }\end{array}$ & Egg Size (mm) & $\begin{array}{c}\text { Gonad Weight } \\
\text { (g) }\end{array}$ \\
\hline Weight & 1 & & & & & & \\
\hline Total Length & $0.771 *$ & 1 & & & & & \\
\hline Standard Length & $0.785 *$ & $0.990 *$ & 1 & & & & \\
\hline Fecundity & 0.398 & $0.479 *$ & $0.442 *$ & 1 & & & \\
\hline $\begin{array}{l}\text { Condition } \\
\text { Factor }\end{array}$ & 0.380 & -0.270 & -0.247 & -0.113 & 1 & & \\
\hline Egg Size & 0.318 & 0.322 & 0.287 & $0.822^{*}$ & -0.030 & 1 & \\
\hline Gonad Weight & $0.423 *$ & $0.506 *$ & $0.467 *$ & $0.992 *$ & -0.122 & $0.818^{*}$ & 1 \\
\hline
\end{tabular}

*Correlation is significant at the 0.05 level

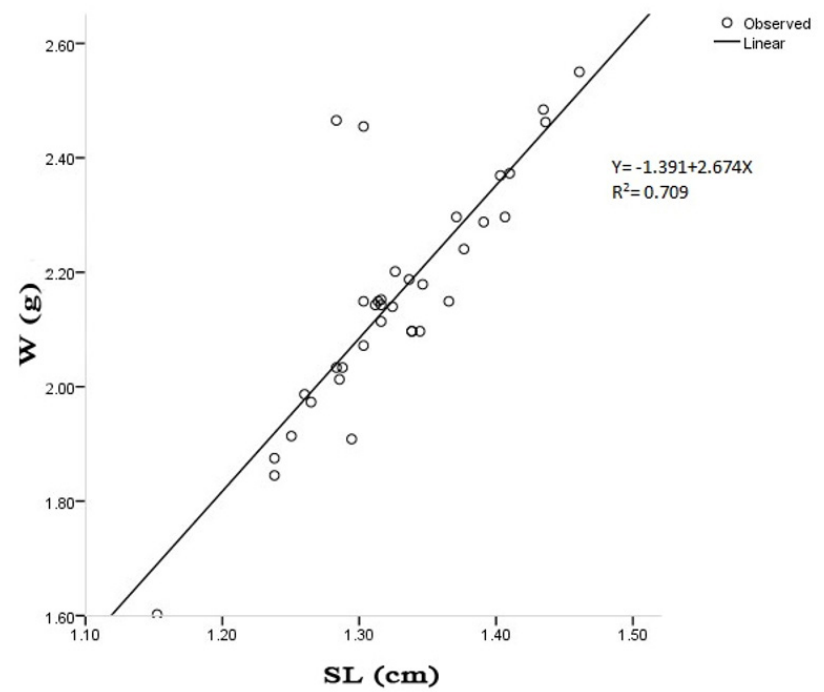

Fig 1. Length-weight relationship of Parachanna obscura (females) collected from the Anambra River

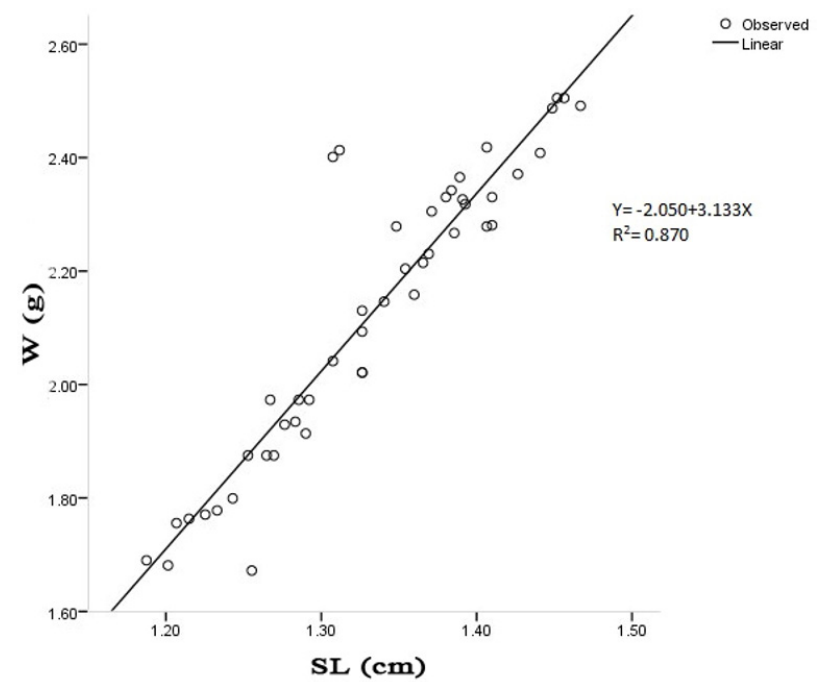

Fig 2. Length-weight relationship of Parachanna obscura (males) collected from the Anambra River

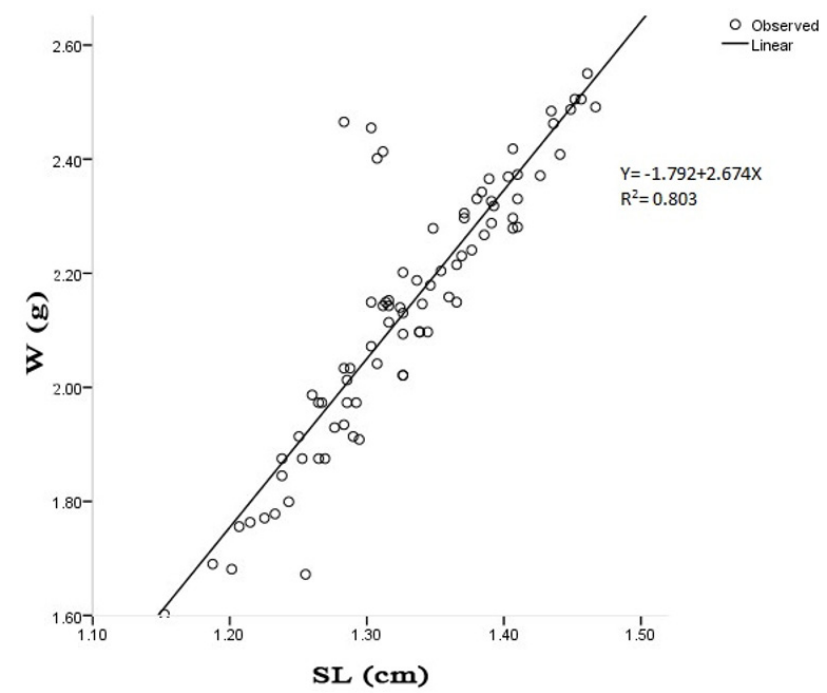

Fig 3. Length-weight relationship of Parachanna obscura (combined sexes) from the Anambra River

also reported a negative pattern of allometric growth in the research conducted on four fish species including Tilapia zilli, Oreochromis niloticus and others from Wassai Reservoir in Kano. However, Garba and Arome (2006) reported isometric growth pattern for Malapterurus electricus from the lower Benue River and as well as similar findings on Ethmalosa frimbiata and Ilisha africana from the Nkoro River (Abowei et al., 2009). The present results may be attributed to age, sex, sampling methods, sample size, as well as the prevailing ecological conditions in the water (Obasohan et al., 2012).

The study showed the condition factor of $P$. obscura from the Anambra River ranged between 0.89 and 0.80 for males and females, respectively. Condition factor is an index used for monitoring feeding intensity, age and growth rate in fish. It is strongly influenced by both abiotic and biotic environment conditions and can be used to assess the status of the aquatic ecosystem in which fish live (Anene, 2005). It was reported by Odo (2007) that 
some of the water quality parameters were unsuitable for aquatic biota and fish production in the Anambra River. Oil exploration and exploitation in the Niger Delta of Nigeria have been seen as the major sources of threats to environmental management and sustainability of this river (Obiakor et al., 2014). The results of condition factor were less than 1 and are in tandem with the findings of Obasohan et al. (2012) who recorded values less than 0.5 and 0.9 for Papyrocranus afer and P. obscura, respectively. These results may be attributed to different factors such as sex, age, state of maturity, size, state of stomach fullness and environmental factors affecting fish in water bodies (Ama-Abasi, 2007; Yem et al., 2007; Adeyemi et al., 2009). The sampled fish exhibited wide variations in the number of eggs, with larger samples producing more eggs than the smaller ones. However, the highest number of eggs was not found in the largest fish and the lowest number of eggs was not found in the smallest fish. Different fish species present a lot of differences in their reproductive potential (Murua et al., 2003). Fecundity of fishes varies, depending on the reproductive characteristics of a species, changes in environmental conditions such as temperature, food availability, habitat and predation intensity (Murua et al., 2003). Similarly, Mekkawy and Hassan (2011) associated changes in fecundity with age, sex, size weight, gonad weight and locality. Olurin and Savage (2011) reported a range of 1711 to 4000 for $P$. obscura weighing between 161.94 and $380.78 \mathrm{~g}$ from the Oshun River, Southwest Nigeria. There was a high correlation coefficient between the Fecundity (F) and Gonad Weight (GW), which is $r$ $=0.992$. This result corroborated with the findings of Rheman et al. (2002) reported for Liza parsia. Similar findings were also reported by Shinkafi and Ipinjolu (2012). There was a moderate correlation between fecundity and body weight. This result is in line with the findings of Shaheena (2012) from Dal Lake Kashmir for Carassius carasssius. Fecundity also correlated to length and weight in P. obscura (Victor and Akpocha, 1992).

According to Hulata et al. (1974), large egg size enhances fry and larval viability due to its higher yolk content, and hence food supply to the larva. In this present study, the egg size ranged between 0.90 and $1.30 \mathrm{~mm}$, which were fairly large. Olurin and Savage (2011) reported egg size which ranged between 0.88 and $1.11 \mathrm{~mm}$ for snake head fish from the River Oshun. There was strong correlation coefficient between fecundity and egg size, which is $r=$ 0.822 . The result indicated that the number of eggs will increase by $82 \%$ as the weight of gonad increases. The result also revealed that gonad weight will increase as the body weight increases.

In this study, the GSI in the females ranged between 0.50 and 5.84. Olurin and Savage (2011) observed a range between 1.10 and 2.80 for $P$. africana from the River Oshun. The hepatosomatic index of this present study ranged from 0.31 to 1.56 , and between 0.22 to 1.06 for male and female $P$. obscura, respectively. This result showed that hepatosomatic indices of male were higher than those of female $P$. obsura. Kareem et al. (2016) reported that a fish living in favourable environment in terms of food availability and good environmental conditions grow faster with $\mathrm{K} \geq 1$. However, most of the documented condition factor results of $P$. obscura from Nigeria's freshwater environment have reported values less than 1. Obasohan et al. (2012) recorded values less than 0.5 and 0.9 for Papyrocranus afer and P. obscura, respectively, from the Ibiekuma stream, Ekpoma, Edo state, Nigeria. Bassey and Ajah (2010) also documented condition factors ranging between 0.63 and 0.79 for pond cultured $P$. obscura given different feed types in Calabar, Nigeria, while Oyelese (2006) recorded a value of 0.80 for $P$. obscura from Ibadan, Southwest Nigeria. Results from the present work are, therefore, within the ranges that have been documented for captured and cultured $P$. obscura in Nigeria. These patterns of obtained results might be owed to the fact that the species is highly streamlined and not a robust fish or round. Freose (2006) and Treer et al. (2009) concluded that different body forms of fish such as elongated, fusiform and short or deep body types have significant effect on condition factors.

\section{SAŽETAK}

\section{DUŽINSKO-MASENI ODNOS, FAKTOR KONDI- CIJE I PLODNOST AFRIČKE ZMIJOGLAVE RIBE Parachanna obscura IZ RIJEKE ANAMBRA, JU- GOISTOČNA NIGERIJA}

Utvrđen je dužinsko-maseni odnos, faktor kondicije, plodnost te gonadosomatski i hepatosomatski indeksi za Parachanna obscura iz rijeke Anambre. Od ribara je dobiveno 83 živih jedinki $P$. obscura. Za analizu dobivenih podataka korištena je deskriptivna statistika, korelacijska i regresijska analiza. Odnos dužine i mase imao je R vrijednosti 0,933, 0,843 i 0,896 za muške, ženske $i$ kombinirane spolove. Vrijednost $b$ je varirala od 3,133 za mužjake i 2,667 za ženke i nije se značajno razlikovala. Faktor kondicije je iznosio $0,89 \pm 0,33$ i $0,80 \pm$ 0,21 za ženke odnosno mužjake. Najveći broj jaja (10.965) nađen je u ženki tjelesne mase $154 \mathrm{~g}$, mase gonada 9,1 $\mathrm{g}$ i veličine jaja $1,3 \mathrm{~mm}$. Najmanje plodna ženka je bila $\mathrm{s}$ 1820 jaja, mase $(94 \mathrm{~g})$, masom gonada $2,1 \mathrm{~g}$ s veličinom jaja $1,0 \mathrm{~mm}$. Hepatosomatski indeksi bili su u rasponu od $0,55 \pm 0,20$ do $0,64 \pm 0,29$ u mužjaka odnosno ženki, dok je prosjek gonadosomatskog indeksa ženki iznosio 2,05 \pm 1,44 . Utvrđena je pozitivna korelacija između plodnosti i mase gonada.

Ključne riječi: Alometrijski rast, masa gonada, hepatosomatski indeks, gonadosomatski indeks. 


\section{REFERENCES}

Abowei, F. N., Hart, A. I. (2009): Some morphometric parameters of 10 finfish species from the lower Nun River, Niger Delta, Nigeria. Research Journal of Biological Sciences.4, 3, 282-288.

Adeyemi, S.O., Bankole N.O., Adikwu I. A., Akombo P. M. (2009): Age, growth mortality of some commercially important fish species in Gbadikere Lake, Kogi State, Nigeria. International Journal of Lakes and Rivers Resources, 2, 1, 63-69.

Afonso-Dias, I., Reis C., Andrade P. (2005): Reproductive Aspects of Microchiru sazevia (Risso, 1810) (Pisces: Soleidae) from the south coast of Portugal. African Journal of Applied Zoology, 9, 13-19.

Ama-Abasi, D., Affia I. N. (2010): Aspects of the biology of Snakeshead, Parachanna obscura (Gunther 1861) in the Cross River Nigeria. Global Journal of Agricultural Sciences, 9, 2, 7-13.

Anene, A. (2005): Condition Factors of Cichlid Species of Man-made Lake in Imo State, Southeast, Nigeria. Journal of Fish and Aquatic Science, 5, 43-47.

Anyanwu, D. C. Mkpado M., Ohaka C.C (2009): Economic Analysis of Artisanal Fishing at River Niger Onitsha, Anambra State, Nigeria. Agro-Science Journal of Tropical Agriculture, Food, Environment and Extension, 8, 3,: $175-179$.

Bagenal, T.B., Tesch, F.W. (1978): Age and growth. In T.B. Bagenal (eds). Methods for the assessment of fish production in freshwater. IBP Handbook No. 3. Blackwell Scientific Publications, Oxford., 101-136pp.

Bassey, A. U., Ajah, P. O. (2010): Effect of three feeding regimes on growth, condition factor and food conversion tate of pond cultured Parachanna obscura (Gunther, 1861) (Channidae) in Calabar, Nigeria. Turkish Journal of Fisheries and Aquatic Sciences 10, 195-202.

Bolaji, B. B., Mfon, T. U., Utibe, D. I. (2011): Preliminary study on the aspects of the biology of Snakehead fish, Prachanna obscura in a Nigerian wetland. African Journal of Food and Agriculture, 1, 1-4.

Eyo, J. E., Mgbenka, B. O. (1992): Aspects of the biology of Clarias gariepinus in Anambra River Basin. 1. Oocyte diameter, fecundity and sex ratio. Journal of

Agricultural Science Technology 2, 1, 47-51.

Froese, R. (2006): Cube law, condition factor and weightlength relationships: history, meta-analysis and recommendations. Journal of Applied Ichthyology, 22, 241-253

Garba, O. F., Arome, A. G. (2006): Growth, reproduction and feeding biology of Malapterurus electricus (Gmelin, 1789 ) in Lower Benue River, Nigeria. In: Proceedings of the 21st Annual Conference of the Fisheries Society of Nigeria, Calabar, $117-128$.

Hulata, G., Moav, R., Wohlfarth, G. (1974): The relationship of gonad and egg size to weight and age in the European and Chinese races of common carp, Cyprinus carpio L. Journal of Fish Biology, 6, 745-758.

Imam, T. S., Bala, U., Balarabe, M. L., Oyeyi, T.I. (2010). Length-weight relationship and condition factor of four fish species from Wasai Reservoir in Kano, Nigeria. African Journal of General Agriculture, 6, 3, 101-136.

IUCN, (2016): IUCN red list of threatened species. Version 2016.1 IUCN 2016. IUCN red list of threatened species. Downloaded 15 July, 2016

Jamu, D. M., Ayinla, A. O. (2003): Potential for the development of agriculture in Africa. NAGA, 26, 3, 9-13.

Kareem, O. K., Olanrewaju, A. N., Osho, E. F., Orisasona, O., Akintunde, M. A. (2016): Growth patterns and condition factor of Hepsetus odoe (Bloch, 1794) captured in Eleyele Lake, Southwest Nigeria. Fisheries and Aquaculture Journal 7: 178-185.

Kpogue, D. N. S., Mensah, G. A., Fiogbe, E. D. (2013): A review of biology, ecology and prospects for aquaculture of Parachanna obscura. Reviews in Fish Biology and Fisheries, 23, 1, 41-50.

Mekkawy, I. A. A., Hassan, A. A. (2011): Some reproductive parameters of Synodontis Schall (Bloch and Schneider, 1801) from the River Nile, Egypt. Journal Fisheries and Aquatic Science, 6, 456-471.

Murua, H., Kraus, G., Saborido-Rey F., Witthames P. R., Thorsen A., Junquera S. (2003): Procedures to estimate fecundity of marine fish species in relation to their reproductive strategy. Journal of Northwest Atlantic Fish. Sci., 33, 33-54.

Obasohan, E. E., Obasohan, E. E., Imasuen, J. A., Isidahome, C. E. (2012): Preliminary studies of the length-weight relationships and condition factor of five fish species from Ibiekuma Stream, Ekpoma, Edo State, Nigeria. Journal of Agricultural Research and Development, 2, 3, 61-69.

Obiakor, M. O., Okonkwo, J. C., Ezeonyejiaku, C. D., Okonkwo, C. N. (2014): Polycyclic Aromatic Hydrocarbons (PAHs) in freshwater media: Factorial effects and human dietary exposure risk. Assessment Resources and Environment, 4, 6, 247-259.

Odo, G. E., Nwani, C. D., Ngwu, G. I., Eyo, J. E. (2007): Harnessing aquatic physicochemical parameters influencing macroinvertebrate fauna in Anambra River Basin for sustainable fish productivity. Animal Research International, 4, 2, 705- 712.

Olurin, K. B., Savage, O. D. (2011): Reproductive biology, length-weight relationship and condition factor of Parachanna obscura, from River Oshun, Southwest Nigeria. International Journal of Fisheries and Aquaculture, 3, 8, 146 - 150.

Osho, E. F., Ajani, E. K., Omitoyin. B. O., Aniebo, V. (2014): Physical masculinization and growth performance of Oreochromis niloticus placed on $17 \alpha$-methyltestosterone treated diet. Journal of Environmental Extension, 12, 41-45. 
Oyelese, O. A. (2006): Implications of carcass quality and condition factor to the processing of some selected freshwater fish families. Journal of Fisheries International, 1, 132-138.

Pepple, P. C., Ofor, C. O. (2011): Length-Weight relationship of Heleterobranchus longifilis reared in earthen ponds, Nigerian Journal of Fisheries, 8, 2, 315-321.

Rheman, S., Islam, M. L., Shah, M. M. R., Mondal, S., Alam, M. J. (2002): Observation on the fecundity and gonadosomatic index (GSI) of Grey Mullet, Liza parsia (Ham.). Journal of Biological Sciences, 2, 10, 690-693.

Ricker, W. E. (Ed.) (1971): Methods for assessment of fish reproduction in freshwaters. IBP Handbook No. 3, Blackwell Scientific Publications, Oxford. 98-130pp.

Shaheena, S. (2012): Study on fecundity and GSI of Carassius carassius (Linneaus, 1758 introduced) from Dal Lake Kashmir. Journal of Biology, Agriculture and Healthcare. 2, 68-75.

Shinkafi, B. A., Ipinjolu, J. K. (2012): Gonadosomatic index, fecundity and egg size of Auchenoglanis occidentalis (Cuvier and Valenciennes) in River Rima, North-western Nigeria. Nigerian Journal of Basic and Applied Science, 20, 3, 217-224.

Tesch, F. W. (1978): Age and growth. In: Ricker, W. E. (Ed.) (1971) Methods for assessment of fish reproduction in freshwaters. IBP Handbook No. 3, Blackwell Scientific Publications, Oxford. 98-130.
Treer, T., Piria, M., Šprem, N. 2009: The relationship between condition and form factors of freshwater fishes of Croatia. Journal of Applied Ichthyology, 25, 608-610

Victor, R., Akpocha, B. O. (1992): The biology of snakehead, Parachanna obscure (Gunther), in a Nigerian pond under monoculture: Aquaculture, 101, 17-24

Whenu, O. O., Fagade, S. O. (2012): Dietary pattern of the population of Parachanna obscura, in River Owo, Southwest, Nigeria. Journal of Fisheries and Aquatic Science 7, 49-56.

Yeldan, H., Avsar, D. (2000): A preliminary study on the reproduction of the Rabbit fish Siganus rivulatus (Forsskal. 1775) in the North-eastern Mediterranean. Journal of Zoololgy. 24, 173-182.

Yem, I. Y., Sani, O. A., Mshelia, M. B, Onimisi, H. U. (2007): The length-weight relationship and condition factor of the Banded Jewel fish (Hemichromis fasciatus) from Kainji Lake, Nigeria. In: Proceedings of the 22nd Annual Conference of the Fisheries Society of Nigeria, 4, 1523. 